\title{
PERAN KEPUASAN KERJA MEMEDIASI KOMUNIKASI TERHADAP KINERJA KARYAWAN
}

\author{
A.A. Didi Hermawan ${ }^{1}$ \\ I Gusti Made Suwandana ${ }^{2}$
}

\author{
${ }^{1,2}$ Fakultas Ekonomi dan Bisnis Universitas Udayana, Bali, Indonesia \\ E-mail: gungggdidi@yahoo.com
}

\begin{abstract}
ABSTRAK
Penelitian ini dilakukan di PT. Nadia Kencana. Jumlah sampel yang diambil sebanyak 78 karyawan, dengan metode yang digunakan adalah sampel jenuh. Pengumpulan data diperoleh dari hasil penyebaran kuisioner. Analisis data menggunakan analisis jalur, analisis sobel dan analisis VAF. Hasil penelitian ini ditemukan bahwa Komunikasi berpengaruh positif dan signfikan terhadap Kepuasan Kerja karyawan. Komunikasi berpengaruh positif dan signfikan terhadap kinerja karyawan. Kepuasan Kerja berpengaruh positif dan signifikan terhadap kinerja karyawan. Kepuasan Kerja secara positif dan signifikan memediasi pengaruh Komunikasi terhadap kinerja karyawan. Implikasi penelitian ini diharapkan pimpinan mampu menjalin komunikasi yang baik guna memberikan kepuasan kerja pada karyawan. Semakin terpuaskan karyawan, maka karyawan akan semakin menunjukkan kinerja terbaiknya guna dapat menciptakan hasil kerja yang lebih efektif dan efisien. Keterbatasan penelitian ini hanya dapat diterapkan dalam lingkungan kerja PT. Nadia Kencana dan tidak dapat direalisasikan pada lingkungan perusahaan lain. Serta pemberian hasil kuesioner yang cukup lama sehingga memperlambat pengolahan data
\end{abstract}

Kata kunci: kepuasan kerja, komunikasi dan kinerja karyawan

\section{ABSTRACT}

This research was conducted at PT. Nadia Kencana. The number of samples taken is 78 employees, with the method used is a saturated sample. Data collection is obtained from the results of questionnaires. Data analysis using path analysis, sobel analysis and VAF analysis. The results of this study found that communication has a positive and significant effect on employee job satisfaction. Communication has a positive and significant effect on employee performance. Job Satisfaction has a positive and significant effect on employee performance. Job Satisfaction positively and significantly mediates the influence of Communication on employee performance. The implication of this research is that leaders are expected to be able to establish good communication in order to provide job satisfaction to employees. The more satisfied the employee, the employee will increasingly show his best performance in order to create more effective and efficient work results. The limitations of this study can only be applied in the work environment of PT. Nadia Kencana and cannot be realized in other company environments. As well as giving the results of the questionnaire long enough to slow down data processing

Keywords: job satisfaction, communication and employee performance 


\section{PENDAHULUAN}

Sumber daya manusia merupakan faktor penting yang menjadi tonggak perkembangan suatu perusahaan (Utamajaya dan Sriathi, 2015). Sumber daya manusia juga merupakan salah satu faktor bagi kelancaran aktifitas yang ada di dalam perusahaan, karena sebagian aktifitas di perusahaan memerlukan sumber daya yang berkualitas agar tercapainya tujuan perusahaan (Robbins, 2001). Sumber daya manusia adalah salah satu elemen penting yang akan menentukan berhasil atau tidaknya suatu perusahaan mencapai tujuan yang telah ditetapkan.

Setiap organisasi dituntut mampu berkompetisi agar dapat tetap bertahan dalam persaingan global. Strategi untuk selalu dapat berkompetisi adalah dengan cara memperkuat kapasitas organisasi dan sumber daya manusia yang dimiliki (Sudarmanto,2009:1). Akan tetapi masalah sumber daya manusia menjadi tantangan tersendiri bagi manajemen karena keberhasilan manajemen tergantung pada kualitas sumber daya manusia. Apabila sumber daya manusia dalam perusahaan dapat berjalan efektif maka perusahaan pun tetap berjalan efektif, dengan kata lain kelangsungan hidup perusahaan tergantung dari kinerja karyawan. Maka selaras dengan yang dikemukakan Handoko (2003:223), bahwa sumber daya yang terpenting dalam suatu organisasi adalah sumber daya manusia yaitu orang-orang yang memberikan tenaga, bakat, kreativitas dan usaha mereka kepada organisasi agar tercapainya kinerja yang optimal dalam suatu perusahaan.

Lewa dan Subowo (2005), menyatakan bahwa kinerja karyawan merupakan hasil kerja yang dicapai seseorang dalam melaksanakan tugas-tugas yang dibebankan kepadanya. Hasan dkk. (2012), mengungkapkan kinerja merupakan 
hasil kerja (kualitas dan kuantitas) dari seorang karyawan dalam periode tertentu sesuai dengan tanggung jawab yang diberikan. Kinerja dapat dinilai dari apa yang dilakukan oleh seorang pegawai dalam kerjanya. Dengan kata lain, kinerja individu adalah bagaimana seorang pegawai melaksanakan pekerjaannya. Kinerja dapat disebut prestasi kerja, dimana merupakan salah satu faktor penentu keberhasilan perusahaan. Hasil kerja yang dicapai oleh seseorang dalam melakukan tugas sesuai dengan tanggung jawab yang diberikan kepadanya adalah cerminan prestasi kerja karyawan masing-masing. Menurut Wibowo (2012:81), menyatakan bahwa kinerja merupakan suatu proses tentang bagaimana pekerjaan berlangsung untuk mencapai hasil kerja. Berbeda halnya dengan Rivai (2012:309), menyatakan kinerja adalah prilaku nyata yang ditampilkan setiap orang sebagai prestasi kerja yang dihasilkan oleh karyawan sesuai dengan peranannya diperusahaan.

Menurut Setiyawan dan Waridin (2006), kinerja karyawan merupakan hasil kerja karyawan yang dinilai dari segi kualitas maupun kuantitas berdasarkan standar kerja yang ditentukan oleh pihak organisasi. Peningkatan kinerja karyawan akan membawa kemajuan bagi perusahaan untuk dapat mencapai tujuan dari perusahaan tersebut. Oleh karena itu upaya-upaya untuk meningkatkan kinerja karyawan merupakan tantangan manajemen yang paling serius karena keberhasilan untuk mencapai tujuan dan kelangsungan hidup perusahaan tergantung pada kualitas kinerja sumber daya manusia yang ada didalamnya. Dalam meningkatkan kinerja karyawan, selain memiliki modal yang besar perusahaan juga harus memiliki sumber daya manusia yang berkualitas, atau saat 
ini yang lebih dikenal dengan nama manajemen kinerja untuk memenangkan persaingan yang ada. Wibowo (2012:7) manajemen kinerja adalah bagaimana mengelola seluruh kegiatan organisasi untuk mencapai tujuan organisasi yang telah ditetapkan sebelumnya. Kualitas sumber daya manusia adalah kinerja individu yang memilki kemampuan untuk memenuhi kewajiban kerjanya, baik itu dari kualitas serta kuantitas pekerjaan dan waktu kerja menurut kriteria yang sudah ditentukan oleh perusahaan. Kinerja karyawan dapat ditingkatkan dengan cara melakukan komunikasi secara terbuka dan terus menerus antara perusahaan dengan para karyawannya tentang kekuatan, kelemahan pasar dan tantangan bisnis yang dihadapi.

Novita et al. (2002), menemukan komunikasi yang efektif antara atasan dan bawahan sangat berpengaruh terhadap kepuasan kerja karyawan sehingga kinerja akan lebih optimal. Razi dan Elizabeth (2010), dalam penelitiannya juga menjelaskan bahwa komunikasi merupakan variabel yang tidak dapat dikesampingkan dalam usaha perusahaan meningkatkan kinerja. Redi Panuju (2001:1), mengemukakan bahwa komunikasi adalah sistem aliran yang menghubungkan dan kinerja antar bagian dalam organisasi sehingga menghasilkan suatu sinergi.

Komunikasi organisasi adalah komunikasi yang berlangsung dalam lingkungan organisasi meliputi pengiriman dan penerimaan pesan-pesan antara dua orang atau lebih, antara sekelompok orang, atau dalam satu atau beberapa bidang yang mempengaruhi perilaku organisasi. Sumarsan (2013), mengatakan komunikasi adalah proses penyampaian pesan dari pengirim (sender) kepada 
penerima (receiver atau audience). Masmuh (2010:9), mengemukakan komunikasi organisasi merupakan pengiriman dan penerimaan berbagai pesan di dalam organisasi, di dalam kelompok formal maupun informal organisasi.

Fahmi (2016:163), menyatakan bahwa komunikasi adalah proses penyampaian pesan atau maksud yang dilakukan melalui satu pihak atau seseorang kepada pihak atau orang lain baik dilakukan secara langsung atau melalui media. Femi (2014), menyatakan bahwa komunikasi yang efektif antara atasan dan bawahan sangat penting bagi keberhasilan perusahaan. Kiswanto (2010), menyatakan bahwa komunikasi berpengaruh signifikan terhadap kinerja karyawan. Ardana dkk. (2012:138), menyatakan bahwa dengan komunikasi seseorang dapat menyampaikan keinginannya yang terpendam di dalam hatinya kepada orang lain, baik melalui suara atau gerak, isyarat anggota badan dan sebagainya.

Menurut Luthans (1998), merumuskan kepuasan kerja adalah suatu keadaan emosi seseorang yang positif maupun menyenangkan yang dihasilkan dan penilaian suatu pekerjaan atau pengalaman kerja. Menurut Robbins (2003:78) kepuasan kerja adalah sikap umum terhadap pekerjaan seseorang yang menunjukkan perbedaan antara jumlah penghargaan yang diterima pekerja dan jumlah yang mereka yakini seharusnya mereka terima. Robbins dan Judge (2008:98), mendefinisikan “Kepuasan kerja merupakan suatu perasaaan positif tentang pekerjaan seseorang yang merupakan hasil dari sebuah evaluasi karakteristiknya". 
Kepuasan kerja merupakan area yang penting dalam organisasi (Awang et al., 2010). Kepuasan kerja diartikan sebagai sikap umum seseorang terhadap pekerjaannya atau dapat juga diartikan sebagai perbedaan antara jumlah imbalan atau penghargaan yang diterima oleh karyawan dan jumlah seharusnya mereka dapatkan (Robbins, 2003: 148). Kepuasan kerja adalah reaksi afektif umum atau global yang dimiliki individu terhadap pekerjaan mereka (Javad dan Davood,2012).

Vidianingtyas (2014), Kepuasan kerja dapat diartikan sebagai seperangkat perasaan pegawai tentang menyenangkan atau tidaknya pekerjaan mereka. Perasaan senang ataupun tidak senang ini muncul disebabkan karena pada saat karyawan bekerja mereka membawa serta seperangkat keinginan, kebutuhan, hasrat dan pengalaman masa lalu yang membentuk harapan kerja mereka. Makin tinggi harapan kerja dapat terpenuhi, maka makin tinggi tingkat kepuasan kerja karyawan. Dari penjelasan diatas dapat disimpulkan bahwa kepuasan kerja sangat berpengaruh terhadap kinerja karyawan di dalam perusahaan. Purwanto (2013), menyatakan bahwa kepuasan kerja mejadi faktor penting dalam meningkatkan kinerja karyawan.

Penelitian ini dilaksanakan di PT. Nadia Kencana yang merupakan salah satu perusahaan yang bergerak di bidang jasa transportasi. Tujuan dari penelitian yang dilakukan di PT. Nadia Kencana yaitu untuk meningkatkan kinerja karyawan agar tetap mampu bersaing di PT. Nadia Kencana dan melakukan usaha untuk dapat mencari sumber daya manusia yang berkualitas agar mampu memberikan pelayanan yang memuaskan kepada konsumen. 
PT. Nadia Kencana tentu tidak terlepas dari berbagai masalah, terutama masalah yang ada hubungannya dengan kinerja karyawan. Davis dan Newstrom (2007:107) menyatakan bahwa karyawan yang motivasinya rendah cenderung melalaikan pekerjaan salah satunya dalam bentuk ketidakhadiran yang tinggi dan juga dapat dilihat dari kinerja karyawannya yang rendah. Tingkat absensi karyawan PT. Nadia Kencana dapat dilihat pada Tabel 1 berikut.

Tabel 1.

Tingkat absensi karyawan PT. Nadia Kencana 2017

\begin{tabular}{ccccccc}
\hline No & Bulan & $\begin{array}{c}\text { Hari } \\
\text { Kerja }\end{array}$ & $\begin{array}{c}\text { Jumlah } \\
\text { Karyawan } \\
\text { (Orang) }\end{array}$ & $\begin{array}{c}\text { Jumlah } \\
\text { Hari } \\
\text { Kerja }\end{array}$ & $\begin{array}{c}\text { Absensi } \\
\text { (Hari) }\end{array}$ & $\begin{array}{c}\text { Presentase } \\
\text { Absensi (\%) }\end{array}$ \\
\hline $\mathbf{1}$ & $\mathbf{2}$ & $\mathbf{3}$ & $\mathbf{4}$ & $\mathbf{5 = 3 \times 4}$ & $\mathbf{6}$ & $\mathbf{7 = 6 / 5 \times 1 0 0 \%}$ \\
1 & Januari & 26 & 78 & 2028 & 81 & 3.99 \\
2 & Februari & 24 & 78 & 1872 & 49 & 2.62 \\
3 & Maret & 26 & 78 & 2028 & 64 & 3.16 \\
4 & April & 23 & 78 & 1794 & 57 & 3.18 \\
5 & Mei & 24 & 78 & 1872 & 78 & 4.17 \\
6 & Juni & 24 & 78 & 1872 & 82 & 4.38 \\
7 & Juli & 26 & 78 & 2028 & 67 & 3.30 \\
8 & Agustus & 26 & 78 & 2028 & 53 & 2.61 \\
9 & September & 24 & 78 & 1872 & 49 & 2.62 \\
10 & Oktober & 26 & 78 & 2028 & 57 & 2.81 \\
11 & November & 26 & 78 & 2028 & 62 & 3.06 \\
12 & Desember & 24 & 78 & 1872 & 49 & 2.62 \\
\multicolumn{7}{c}{ Jumlah } \\
Rata-rata & & $\mathbf{2 3 3 2 2}$ & $\mathbf{7 4 8}$ & $\mathbf{3 8 . 5 1}$ \\
\hline
\end{tabular}

Sumber: Data diolah, 2018

Rata-rata tingkat absensi antara 2-3 persen perbulan masih dianggap baik, jika tingkat absensi $>3-10$ persen maka dianggap tidak wajar. Berdasarkan Tabel 1 diatas dapat dinyatakan bahwa rata-rata persentase karyawan setiap bulannya adalah 3,21 persen. Tingkat absensi terendah terjadi pada bulan Agustus yaitu sebesar 2,61 persen sedangkan pada bulan Januari merupakan tingkat absensi tertinggi yaitu hingga 4,38 persen. Dapat disimpulkan bahwa, rata-rata tingkat absensi karyawan tergolong tinggi karena berada diatas 3 persen. Berdasarkan rata-rata absensi karyawan, tingkat absensi karyawan PT. Nadia Kencana 
termasuk dalam kategori kurang baik, hal tersebut dikarenakan rata-rata persentase absensi karyawan berada diatas 3 persen Oleh karena itu perusahaan harus lebih memperhatikan karyawannya, sebab absensi merupakan salah satu cara untuk menilai kinerja karyawan. Dengan mematuhi peraturan-peraturan kerja perusahaan, karyawan akan dapat bersaing dengan karyawan lainnya dan dengan persaingan tersebut karyawan dapat meningkatkan karir dan termotivasi untuk berprestasi, sehingga dapat menghasilkan kinerja yang maksimal.

Berdasarkan hasil wawancara dengan pimpinan PT. Nadia Kencana terdapat masalah mengenai menurunnya kinerja karyawan yang dapat dilihat pada data absensi karyawan yang menunjukan bahwa tingkat absensi karyawan masih rendah, selain itu kurang yang displin kerja karyawan dan banyaknya mengambil cuti libur saat berkerja. Sedangkan hasil wawancara yang dilakukan oleh 10 karyawan PT. Nadia Kencana mengenai indikasi kinerja karyawan, terdapat faktor-faktor seperti komunikasi dan kepuasan kerja yang mendorong karyawan untuk meningkatkan kinerjanya di PT. Nadia Kencana. Hal ini dapat dilihat dari keluhan yang muncul dari karyawan mengenai gaji yang di dapat yang kurang sesuai dengan kinerja yang telah dihasilkan oleh karyawan terhadap perusahaan, tekanan dari atasan dalam pencapaian target pemasukan perusahaan, kurangannya komunikasi yang baik, seperti ketidak jelasan informasi.

Beberapa kendala komunikasi pada PT. Nadia Kencana menunjukkan bahwa di dalam perusahaan terjadi komunikasi yang belum maksimal. Hal ini disebabkan oleh masih ada hambatan dalam penyampaian suatu informasi dari atasan kepada karyawan. Hambatan yang dimaksud adalah banyaknya saluran 
yang harus dilalui misalnya informasi dari direktur harus melewati manajer dan kepala bagian terlebih dahulu kemudian barulah sampai kepada bawahan. Sehingga adanya kemungkinan perubahan informasi yang akan disampaikan akan terjadi. Padahal kelancaran dalam berkomunikasi sangat berkaitan untuk peningkatan kinerja karyawan melalui kepuasan kerja yang dirasakan oleh karyawan.

Rita (2005) juga menyatakan bahwa komunikasi akan mempengaruhi kepuasan kerja karyawan, karena jika terjalin komunikasi yang baik antara karyawan dan atasan maka karyawan akan menjadi lebih puas. Menurut Hariandja (2002) komunikasi merupakan bagian yang penting dalam kehidupan kerja. Hal ini mudah dipahami sebab komunikasi yang tidak baik bisa mempunyai dampak yang luas terhadap kehidupan organisasi, misalnya konflik antar karyawan, kesenjangan karyawan dan sebaliknya komunikasi yang baik dapat meningkatkan pengertian, kerjasama, dan juga kepuasan kerja karyawan. Beberapa penelitian yang telah dilakukan, ditemukan bahwa adanya hubungan positif secara langsung antara komunikasi dan kepuasan kerja.

Pada penelitian yang dilakukan oleh Ali dan Haider (2012) dikemukakan bahwa ada dampak signifikan dari tiga dimensi komunikasi pada kepuasan kerja. Novita et al. (2002) juga mengemukakan komunikasi efektif antara atasan dan bawahan sangat berpengaruh terhadap kepuasan kerja pegawai. Selanjutnya terdapat pengaruh langsung dari karakteristik individu, komunikasi yang efektif dan kepuasan kerja terhadap kinerja pegawai. Selain itu, penelitian yang 
dilakukan oleh Sudiro dan Sumanang (2005), menyebutkan bahwa komunikasi efektif berpengaruh terhadap kepuasan kerja karyawan.

$\mathrm{H}_{1}$ : Komunikasi berpengaruh positif terhadap kepuasan kerja.

Trijaya (2012), menyatakan bahwa komuikasi berpengaruh secara positif dan signifikan terhadap kinerja karyawan, artinya bahwa semakin tinggi atau baik komunikasi yang ada di perusahaan, maka akan semakin tinggi pula kinerja karyawan yang akan dihasilkan. Novita et al. (2002), menemukan komunikasi yang efektif antara atasan dan bawahan sangat berpengaruh terhadap kepuasan kerja karyawan sehingga kinerja akan lebih optimal. Razi dan Elizabeth (2010), dalam penelitiannya juga menjelaskan bahwa komunikasi merupakan variabel yang tidak dapat dikesampingkan dalam usaha perusahaan meningkatkan kinerja. Redi Panuju (2001:1), mengemukakan bahwa komunikasi adalah sistem aliran yang menghubungkan dan kinerja antar bagian dalam organisasi sehingga menghasilkan suatu sinergi. Purwanto (2013) menyatakan bahwa komunikasi berpengaruh positif signifikan terhadap kinerja karyawan.

$\mathrm{H}_{2}$ : Komunikasi Berpengaruh Positif Terhadap Kinerja Karyawan.

Menurut Mathis dan Jackson (2004), meskipun kepuasan kerja itu menarik dan Peran penting, hal yang paling mendasar adalah pengaruh kepuasan kerja terhadap organisasi yang akan mempengaruhi kinerja karyawan. Putrana (2016), mengemukakan kaitan kepuasan kerja dengan kinerja karyawan ditunjukkan oleh keadaan perusahaan dimana karyawan yang terpuaskan cenderung lebih efektif dari pada perusahaan-perusahaan dengan karyawan yang kurang terpuaskan. Karyawan yang lebih suka menikmati kepuasan kerja dalam pekerjaan akan lebih 
mengutamakan pekerjaannya daripada balas jasa walaupun balas jasa itu penting (Hasibuan, 2012). Menurut Devi (2009), kepuasan kerja berpengaruh positif signifikan terhadap kinerja karyawan. Jadi semakin terpuaskan karyawan, maka karyawan akan semakin menunjukkan kinerja terbaiknya. Sebaliknya, jika karyawan tidak merasa puas dalam bekerja, maka dalam dirinya akan timbul rasa malas, sehingga akan berdampak pada menurunnya kinerja. Hal ini juga sesuai dengan teori yang dikemukakan oleh Robbins (2006) mengenai dampak kepuasan kerja terhadap kinerja karyawan. Robbins menyatakan bahwa karyawan yang puas berkemungkinan lebih besar untuk berbicara secara positif tentang organisasi, membantu yang lain, dan berbuat kinerja pekerjaan mereka melampaui perkiraan normal.

$\mathrm{H}_{3}$ : Kepuasan Kerja Berpengaruh Positif Terhadap kinerja.

Hasil penelitian yang dilakukan Ardiansyah (2016), menyatakan bahwa peran kepuasan kerja memediasi komunikasi dan kinerja karyawan berpengaruh positif.Pada penelitian Carriere dan Bourque (2009), menunjukan bahwa dalam komunikasi berpengaruh terhadap komitmen organisasi yang dimediasi oleh kepuasan kerja. Sedangkan Gray dan Laidlaw (2002), mengemukakan bahwa umpan balik personal, komunikasi pengawas, komunikasi horizontal dan iklim komunikasi berpengaruh signifikan terhadap kepuasan karyawan dan kinerja karyawan. Berdasarkan temuan dari penelitian penelitian tersebut dapat dikemukakan bahwa kepuasan kerja mampu berkolerasi erat dengan komunikasi dan kinerja karyawan baik secara langsung ataupun secara mediasi.

$\mathrm{H}_{4}$ : Kepuasan Kerja Berpengaruh Positif Dalam Memediasi Komunikasi Terhadap kinerja Karyawan 
Komunikasi akan mempengaruhi kepuasan kerja karyawan, karena jika terjalin komunikasi yang baik antara karyawan dan atasan maka karyawan akan menjadi lebih puas (Rita, 2005). Novita et al. (2002) mengemukakan komunikasi efektif antara atasan dan bawahan sangat berpengaruh terhadap kepuasan kerja pegawai. Selanjutnya terdapat pengaruh langsung dari karakteristik individu, komunikasi yang efektif dan kepuasan kerja terhadap kinerja pegawai.

Razi dan Elizabeth (2010), dalam penelitiannya juga menjelaskan bahwa komunikasi merupakan variabel yang tidak dapat dikesampingkan dalam usaha perusahaan meningkatkan kinerja. Redi Panuju (2001:1), mengemukakan bahwa komunikasi adalah sistem aliran yang menghubungkan dan kinerja antar bagian dalam organisasi sehingga menghasilkan suatu sinergi

Karyawan yang lebih suka menikmati kepuasan kerja dalam pekerjaan akan lebih mengutamakan pekerjaannya dari pada balas jasa walaupun balas jasa itu penting (Hasibuan, 2012). Menurut Devi (2009), kepuasan kerja berpengaruh positif signifikan terhadap kinerja karyawan. Jadi semakin terpuaskan karyawan, maka karyawan akan semakin menunjukkan kinerja terbaiknya.

Gray dan Laidlaw (2002), mengemukakan bahwa umpan balik personal, komunikasi pengawas, komunikasi horizontal dan iklim komunikasi berpengaruh signifikan terhadap kepuasan karyawan dan kinerja karyawan.

\section{METODE PENELITIAN}

Lokasi penelitian ini dilakukan di PT. Nadia Kencana yang beralamat di Jl. Mahendradatta No.91, Padangsambian, Denpasar Bar., Kota Denpasar, Bali. 
Lokasi ini dipilih karena terdapat masalah dengan variabel kepuasan kerja, komunikasi, kinerja karyawan.

Populasi dalam penelitian ini adalah seluruh karyawan PT. Nadia Kencana dalam penelitian ini adalah 78 responden dari karyawan. Metode penentuan sampel yang digunakan adalah sampel jenuh, dimana seluruh anggota populasi digunakan sebagai sampel. Sampel dalam penelitian ini adalah seluruh karyawan PT. Nadia Kencana yang berjumlah 78 orang. Teknik analisis data yang digunakan dalam penelitian ini adalah analisis jalur (Path Analysis).

\section{HASIL DAN PEMBAHASAN}

Uji normalitas dalam penelitian ini dilakukan dengan menguji normalitas residual dengan menggunakan uji statistik Kolmogorov-Smirnov. Data dikatakan berdistribusi dengan normal apabila koefisien Asymp. Sig lebih besar dari $\alpha=0,05$ $(\alpha=5 \%)$.

Tabel 2.

Hasil Uji Normalitas Struktur 1

\begin{tabular}{lc}
\hline & Unstandardized Residual \\
\hline $\mathrm{N}$ & 78 \\
Kolmogorov-Smirnov & 0,076 \\
Asymp. Sig (2-tailed) & 0,200 \\
\hline Sumber : Data diolah, 2018
\end{tabular}

Berdasarkan Tabel 2. dapat dilihat bahwa nilai Kolmogorov Sminarnov (KS) sebesar 0,076 sedangkan nilai dari Asymp. Sig (2-tailed) sebesar 0,200. Hasil tersebut mengindikasikan bahwa model persamaan regresi tersebut berdistribusi normal karena nilai Asymp. Sig (2-tailed) sebesar 0,200 dimana lebih besar dari nilai alpha yaitu 0,05. Hasil uji normalitas struktur 2 dapat dilihat pada Tabel 2. 
Tabel 3.

Hasil Uji Normalitas Struktur 2

\begin{tabular}{lc}
\hline & Unstandardized Residual \\
\hline $\mathrm{N}$ & 78 \\
Kolmogorov-Smirnov $Z$ & 0,051 \\
Asymp.Sig (2-tailed) & 0,200 \\
\hline Sumber : Datad diolat 2018
\end{tabular}

Sumber : Data diolah, 2018

Berdasarkan Tabel 3. dapat dilihat bahwa nilai Kolmogorov Sminarnov (K-

S) sebesar 0,051 sedangkan nilai dari Asymp. Sig (2-tailed) sebesar 0,200. Hasil tersebut mengindikasikan bahwa model persamaan regresi tersebut berdistribusi normal karena nilai Asymp. Sig (2-tailed) sebesar 0,200 dimana lebih besar dari nilai alpha yaitu 0,05, yang berarti data berdistribusi normal.

Uji Multikolinieritas bertujuan untuk menguji apakah pada model regresi ditemukan adanya korelasi antar variabel bebas. Model regresi yang baik seharusnya tidak terjadi korelasi antara variabel bebas atau bebas dari gejala multikolinier. Jika model regresi yang mengandung gejala mutlikolinieritas dipaksa untuk digunakan, maka dapat memberikan hasil prediksi yang menyimpang. Untuk mendeteksi ada atau tidaknya korelasi antar sesama variabel bebas dilihat dari nilai tolerance dan nilai inflation factor (VIF), dan bila nilai tolerance lebih dari 0,01 persen atau kurang dari 10 persen, maka tidak ada multikolinieritas. Dengan menggunakan aplikasi SPSS 25.0 for windows. Hasil Uji Multikolinieritas dapat dilihat pada Tabel 3.

Tabel 4.

Hasil Uji Multikoleniaritas

\begin{tabular}{llcc}
\hline \multicolumn{1}{c}{ Persamaan Struktur } & \multicolumn{1}{c}{ Variabel } & Tolerance & VIF \\
\hline $\mathrm{M}=\beta_{1} \mathrm{X}+\mathrm{e}_{1}$ & Komunikasi (X) & 1,000 & 1,000 \\
$\mathrm{Y}=\beta_{1} \mathrm{X}+\beta_{2} \mathrm{M}+\mathrm{e}_{2}$ & Komunikasi (X) & 0,552 & 1,812 \\
& Kepuasan Kerja (M) & 0,552 & 1,812 \\
\hline
\end{tabular}

Sumber : Data diolah, 2018 
Berdasarkan Tabel 4. mendeteksi ada atau tidaknya multikolinearitas dalam model regresi yaitu mempunyai angka Tolerance lebih dari 0,01 atau mempunyai nilai VIF kurang dari 10. Berdasarkan hasil analisis, dapat dilihat bahwa koefisien Tolerance semua variabel lebih besar dari 0,01 dan nilai VIF yang lebih kecil dari 10. Hasil ini mengindikasikan bahwa tidak terdapat gejala multikoleniaritas dari model regresi yang dibuat sehingga pada model regresi ditemukan korelasi antar variabel bebas.

Uji ini bertujuan untuk mengetahui apakah dalam model regresi terjadi ketidaksamaan varians dari residual satu pengamatan ke pengamatan yang lain dan pengujian ini dilakukan dengan uji Glejser. Jika nilai signifikansinya di atas 0,05 maka tidak mengandung gejala heteroskedastisitas.

Tabel 5.

Hasil Uji Heteroskedastisitas Struktur 1

\begin{tabular}{llccccc}
\hline \multirow{2}{*}{ Model } & \multicolumn{2}{c}{$\begin{array}{c}\text { Coefficients } \\
\text { Unstandardized } \\
\text { Coefficients }\end{array}$} & $\begin{array}{c}\text { Standardized } \\
\text { Coefficients } \\
\text { Beta }\end{array}$ & T & Sig. \\
\hline 1 & B & Std. Error & 2.081 & & 2.592 & .011 \\
& (Constant) & 5.393 & .129 & -.103 & -.905 & .368 \\
\hline Komunikasi & -.116 & &
\end{tabular}

Pada Tabel 5. dapat dilihat bahwa nilai signifikansi dari variabel komunikasi sebesar 0,368 . Nilai tersebut lebih besar dari 0,05 yang berarti tidak terdapat pengaruh antara variabel bebas terhadap absolute residual. Dengan demikian, model yang dibuat tidak mengandung gejala heteroskedastisitas karena nilai dari hasil uji heteroskedastisitas sebesar 0,368 yang berarti kurang dari 0,05 dan dapat dikatakan tidak signifikan.

Hasil uji heteroskedastisitas struktur 2 dapat dilihat pada Tabel 6. 
Tabel 6.

Hasil Uji Heteroskedastisitas Struktur 2

\begin{tabular}{|c|c|c|c|c|c|c|}
\hline \multirow{2}{*}{\multicolumn{2}{|c|}{ Model }} & \multicolumn{2}{|c|}{$\begin{array}{l}\text { Unstandardized } \\
\text { Coefficients }\end{array}$} & \multirow{2}{*}{$\begin{array}{c}\text { Standardized } \\
\text { Coefficients } \\
\text { Beta }\end{array}$} & \multirow[t]{2}{*}{$\mathbf{T}$} & \multirow[t]{2}{*}{ Sig. } \\
\hline & & B & Std. Error & & & \\
\hline \multirow[t]{3}{*}{1} & (Constant) & 2.431 & 1.522 & & 1.597 & .114 \\
\hline & Komunikasi & .082 & .097 & .131 & .849 & .399 \\
\hline & Kepuasan Kerja & -.036 & .039 & -.142 & -.918 & .361 \\
\hline
\end{tabular}

Sumber : Data diolah, 2018

Pada Tabel 6. dapat dilihat bahwa nilai signifikansi dari variabel komunikasi, dan kepuasan kerja, masing-masing sebesar 0,399 dan 0,361. Nilai tersebut lebih besar dari 0,05 yang berarti tidak terdapat pengaruh antara variabel bebas terhadap absolute residual. Dengan demikian, model yang dibuat tidak mengandung gejala heteroskedastisitas karena nilai dari hasil uji heteroskedastisitas variabel komunikasi dan kepuasan kerja sebesar 0,399 dan 0,361 yang berarti kurang dari 0,05 dan dapat dikatakan tidak signifikan .

Perhitungan koefisien path dilakukan dengan analisis regresi melalui software SPSS 25.0 for Windows, diperoleh hasil yang ditunjukan pada Tabel 7 berikut.

Tabel 7.

Hasil Analisis Jalur 1

\begin{tabular}{|c|c|c|c|c|c|}
\hline \multirow[t]{2}{*}{ Variabel } & \multicolumn{2}{|c|}{$\begin{array}{c}\text { Unstandardized } \\
\text { Coefficients }\end{array}$} & \multirow{2}{*}{$\begin{array}{c}\text { Standardized } \\
\text { Coefficients } \\
\text { Beta } \\
\end{array}$} & \multirow[t]{2}{*}{$\begin{array}{c}\mathrm{t} \\
\text { hitung }\end{array}$} & \multirow[t]{2}{*}{$\begin{array}{c}\text { Sig. uji } \\
t\end{array}$} \\
\hline & B & Std. Error & & & \\
\hline (Constant) & 25.135 & 3.398 & & 7.398 & .000 \\
\hline Komunikasi (X) & 1.650 & .210 & .669 & 7.854 & .000 \\
\hline R Square & 0,448 & & & & \\
\hline F Statistik & 61,692 & & & & \\
\hline $\begin{array}{l}\text { Signifikansi Uji } \\
F\end{array}$ & 0,000 & & & & \\
\hline
\end{tabular}

Berdasarkan hasil analisis jalur substruktur 1 seperti yang disajikan pada

Tabel 7, maka dapat dibuat persamaan struktural sebagai berikut :

$$
\mathrm{M}=\alpha+\beta_{1} \mathrm{X}+\mathrm{e}_{1}
$$


$\mathrm{M}=25,135+0,669 \mathrm{X}+0,210$

Nilai koefisien regresi variabel orientasi pasar bernilai positif dengan nilai signifikansi uji t kurang dari 0,05. Hal ini menunjukkan bahwa variabel Komunikasi memiliki pengaruh positif yang signifikan terhadap variabel Kepuasan Kerja. Besarnya pengaruh variabel bebas terhadap variabel terikat yang ditunjukkan oleh nilai determinasi total (R Square) sebesar 0,448 mempunyai arti bahwa sebesar 44,8 \% variasi Kepuasan Kerja dipengaruhi oleh variasi Komunikasi, sedangkan sisanya sebesar 55,2\% dijelaskan oleh faktor lain yang tidak dimasukkan ke dalam model.

Tabel 8.

Hasil Analisis Jalur 2

\begin{tabular}{|c|c|c|c|c|c|}
\hline \multirow[t]{2}{*}{ Variabel } & \multicolumn{2}{|c|}{$\begin{array}{c}\text { Unstandardized } \\
\text { Coefficients }\end{array}$} & \multirow{2}{*}{$\begin{array}{c}\text { Standardized } \\
\text { Coefficients } \\
\text { Beta }\end{array}$} & \multirow[t]{2}{*}{$\begin{array}{c}\mathbf{t} \\
\text { hitung }\end{array}$} & \multirow[t]{2}{*}{$\underset{t}{\text { Sig. uji }}$} \\
\hline & B & Std. Error & & & \\
\hline (Constant) & 6.798 & 2.433 & & 2.794 & .007 \\
\hline Komunikasi (X) & .681 & .154 & .388 & 4.410 & .000 \\
\hline $\begin{array}{l}\text { Kepuasan Kerja } \\
\text { (M) }\end{array}$ & .364 & .063 & .512 & 5.813 & .000 \\
\hline R Square & 0,679 & & & & \\
\hline F Statistik & 79,314 & & & & \\
\hline Signifikansi Uji F & 0,000 & & & & \\
\hline
\end{tabular}

Berdasarkan hasil analisis jalur substruktur 2 seperti yang disajikan pada Tabel 8, maka dapat dibuat persamaan struktural sebagai berikut :

$$
\begin{aligned}
& Y=\alpha+\beta_{2} X+\beta_{3} M+e_{2} \ldots \ldots \ldots \ldots \ldots \ldots \ldots \\
& Y=6,798+0,388 X+0,512 M+0,063
\end{aligned}
$$

Nilai koefisien regresi masing-masing variabel bebas bernilai positif dengan nilai signifikansi uji t kurang dari 0,050. Hal ini menunjukkan bahwa semua variabel bebas memiliki pengaruh positif yang signifikan terhadap variabel terikat. Besarnya pengaruh variabel bebas terhadap variabel terikat yang ditunjukkan oleh 
nilai determinasi total (R Square) sebesar 0,679 mempunyai arti bahwa sebesar $67,9 \%$ variasi kinerja karyawan dipengaruhi oleh variasi Komunikasi dan Kepuasan Kerja, sedangkan sisanya sebesar 32,1\% dijelaskan oleh faktor lain yang tidak dimasukkan ke dalam model.

Berdasarkan model substruktur 1 dan substruktur 2, maka dapat disusun model diagram jalur akhir. Sebelum menyusun model diagram jalur akhir, terlebih dahulu dihitung nilai standar eror sebagai berikut :

$$
\begin{aligned}
\mathrm{Pe}_{\mathrm{i}} & =\sqrt{1-\mathrm{R}_{\mathrm{i}}{ }^{2}} \ldots \ldots \ldots \ldots \ldots \ldots \ldots \ldots \ldots \ldots \ldots \ldots \ldots \ldots \ldots \ldots \ldots \ldots \ldots \ldots \ldots \ldots \\
\mathrm{Pe}_{1} & =\sqrt{1-R_{1}{ }^{2}}=\sqrt{1-0,448}=0,743 \\
\mathrm{Pe}_{2} & =\sqrt{1-R_{2}{ }^{2}} \ldots \ldots \ldots \ldots \ldots \ldots \ldots \\
& =\sqrt{1-0,679}=0,567
\end{aligned}
$$

Berdasarkan perhitungan pengaruh error (Pei), didapatkan hasil pengaruh error $\left(\mathrm{Pe}_{1}\right)$ sebesar 0,743 dan pengaruh error $\left(\mathrm{Pe}_{2}\right)$ sebesar 0,567. Hasil koefisien determinasi total adalah sebagai berikut :

$$
\begin{aligned}
\mathrm{R}_{\mathrm{m}}^{2} & =1-\left(\mathrm{Pe}_{1}\right)^{2}\left(\mathrm{Pe}_{2}\right)^{2} \\
= & 1-(0,743)^{2}(0,567)^{2} \\
& =1-(0,552)(0,321) \\
& =1-0,177=0,823
\end{aligned}
$$

Nilai determinasi total sebesar 0,823 mempunyai arti bahwa sebesar $82,3 \%$ variasi kinerja karyawan dipengaruhi oleh variasi Komunikasi dan Kepuasan 
Kerja, sedangkan sisanya sebesar $17,7 \%$ djelaskan oleh faktor lain yang tidak dimasukkan ke dalam model.

Pengaruh langsung dan pengaruh tidak langsung serta pengaruh total antar variabel. Perhitungan pengaruh antar variabel dirangkum dalam Tabel 8 sebagai berikut.

Tabel 9.

Pengaruh Langsung dan Pengaruh Tidak Langsung serta Pengaruh Total Komunikasi (X), Kepuasan Kerja (M), dan Kinerja Karyawan (Y)

\begin{tabular}{cccc}
\hline $\begin{array}{c}\text { Pengaruh } \\
\text { Variabel }\end{array}$ & $\begin{array}{c}\text { Pengaruh } \\
\text { Langsung }\end{array}$ & $\begin{array}{c}\text { Pengaruh Tidak Langsung Melalui } \\
\text { Perceived Value } \\
(\text { Y1) }(\boldsymbol{\beta 1} \mathbf{~} \boldsymbol{\beta 3})\end{array}$ & Pengaruh Total \\
\hline $\mathrm{X} \rightarrow \mathrm{M}$ & 0,669 & - & 0,669 \\
$\mathrm{X} \rightarrow \mathrm{Y}$ & 0,388 & 0,343 & 0,730 \\
$\mathrm{M} \rightarrow \mathrm{Y}$ & 0,512 & - & 0,512 \\
\hline
\end{tabular}

Tabel 9. menunjukkan bahwa pengaruh langsung Komunikasi terhadap Kepuasan Kerja adalah sebesar 0,669. Pengaruh langsung variabel Komunikasi terhadap kinerja karyawan sebesar 0,388. Pengaruh langsung variabel Kepuasan Kerja terhadap kinerja karyawan sebesar 0,512 . Hal ini berarti bahwa variabel kinerja karyawan lebih besar dipengaruhi oleh Kepuasan Kerja dari Komunikasi. Sedangkan pengaruh tidak langsung variabel Komunikasi terhadap kinerja karyawan melalui Kepuasan Kerja sebesar 0,343. Jadi pengaruh total variabel Komunikasi terhadap kinerja karyawan melalui Kepuasan Kerja adalah sebesar 0,730 Jadi dapat disimpulkan bahwa lebih besar total pengaruh Komunikasi terhadap kinerja karyawan yang melalui Kepuasan Kerja, daripada pengaruh langsung Komunikasi terhadap kinerja karyawan tanpa melalui variable Kepuasan Kerja. 
Uji sobel digunakan untuk menguji kekuatan pengaruh tidak langsung variabel Komunikasi $(\mathrm{X})$ terhadap variabel kinerja karyawan $(\mathrm{Y})$ melalui variabel Kepuasan Kerja kerja (M). Pengaruh tidak langsung variabel Komunikasi (X) terhadap variabel kinerja karyawan (Y) melalui variabel Kepuasan Kerja kerja (M).

Untuk menguji signifikansi pengaruh tidak langsung maka nilai $\mathrm{z}$ dari koefisien ab dihitung dengan rumus sebagai berikut :

$$
\begin{aligned}
& S_{a b}=\sqrt{(0,512)^{2}(0,210)^{2}+(0,669)^{2}(0,063)^{2}+(0,210)^{2}(0,063)^{2}} \\
& S_{a b}=0,116
\end{aligned}
$$

Keterangan :

$0,210=$ Standard error koefisien a

$0,063=$ Standard error koefisien $\mathrm{b}$

$0,116=$ Besarnya standard error tidak langsung

$0,669=$ Koefisien jalur X terhadap $\mathrm{M}$

$0,512=$ Koefisien jalur M terhadap $\mathrm{Y}$

Untuk menguji signifikansi pengaruh tidak langsung maka menghitung nilai $\mathrm{z}$ dari koefisien ab dengan rumus sebagai berikut :

$$
\begin{aligned}
& Z=\frac{a b}{S a b} \ldots \ldots \ldots \\
& Z=\frac{(0,669)(0,512)}{0,116} \\
& Z=2,953
\end{aligned}
$$

Oleh karena Z hitung sebesar 2,953 > 1,96. Artinya Kepuasan Kerja Berpengaruh Positif Dalam Memediasi Komunikasi Terhadap kinerja Karyawan

Hasil pengujian mediasi dengan metode VAF dalam penelitian ini telah memenuhi beberapa persyaratan yaitu, pertama, pengaruh langsung ditemukan 
signifikan (a) saat variabel kepuasan kerja (M) belum dimasukkan ke dalam model. Kedua, setelah variabel kepuasan kerja (M) dimasukkan ke dalam model, maka pengaruh tidak langsung ( $\mathrm{b}$ x c) ditemukan pula signifikan. Jalur yaitu $\mathrm{b}$ dan c juga signifikan. Ketiga, menghitung Variance Accounted For (VAF) dengan rumus:

$$
\begin{aligned}
\mathrm{VAF} & =(0,669 \times 0,512) /(0,669+0,512 \times 0,730) \\
& =0,343 / 1,043 \\
& =0,329 \text { atau } 32,9 \text { persen. }
\end{aligned}
$$

Karena nilai VAF $(32,9$ persen) lebih dari 20 persen, maka dapat dijelaskan bahwa ada efek mediasi. Dengan demikian, maka hipotesis yang menyatakan bahwa kepuasan kerja memediasi pengaruh kualitas pelayanan terhadap kepercayaan konsumen diterima.

Pengaruh komunikasi terhadap kepuasan kerja diperoleh nilai Signifikansi sebesar 0,000 dengan nilai koefisien beta 0,669 bernilai positif. Nilai Signifikansi $0,000<0,05$ mengindikasikan bahwa $\mathrm{H}_{0}$ ditolak dan $\mathrm{H}_{1}$ diterima. Hasil ini mempunyai arti bahwa Komunikasi berpengaruh positif terhadap kepuasan kerja. Artinya semakin baik komunikasi yang diberikan oleh PT. Nadia Kencana maka semakin kuat tingkat kepuasan kerja karyawan tersebut. Hasil penelitian ini sesuai dengan hipotesis yang diajukan dan juga sesuai dengan hasil penelitian yang dilakukan oleh Sudiro dan Sumanang (2005), menyebutkan bahwa komunikasi efektif berpengaruh terhadap kepuasan kerja karyawan. Penelitian ini sejalan dengan penelitian yang dilakukan oleh Novita et al. (2002) yang mengemukakan komunikasi efektif antara atasan dan bawahan sangat berpengaruh terhadap 
kepuasan kerja pegawai. Selanjutnya terdapat pengaruh langsung dari karakteristik individu, komunikasi yang efektif dan kepuasan kerja terhadap kinerja pegawai.

Pengaruh komunikasi terhadap kinerja karyawan diperoleh nilai Signifikansi sebesar 0,048 dengan nilai koefisien beta 0,388 bernilai positif. Nilai Signifikansi $0,000<0,05$ mengindikasikan bahwa $\mathrm{H}_{0}$ ditolak dan $\mathrm{H}_{2}$ diterima. Hasil ini mempunyai arti bahwa Komunikasi Berpengaruh Positif Terhadap Kinerja Karyawan. Artinya semakin baik komunikasi yang diberikan oleh PT. Nadia Kencana maka semakin kuat tingkat kinerja karyawan tersebut. Hasil penelitian ini sesuai dengan hipotesis yang diajukan dan juga sesuai dengan hasil penelitian yang dilakukan oleh Novita et al. (2002), Razi \& Elizabeth (2010), Redi Panuju (2001), yang menyatakan bahwa komunikasi berpengaruh positif dan signifikan terhadap kinerja. Artinya komunikasi yang baik dapat meningkatkan tingkat kinerja karyawan.

Pengaruh kepuasan kerja terhadap kinerja karyawan diperoleh nilai Signifikansi sebesar 0,000 dengan nilai koefisien beta 0,512 bernilai positif. Nilai Signifikansi $0,000<0,05$ mengindikasikan bahwa $\mathrm{H}_{0}$ ditolak dan $\mathrm{H}_{3}$ diterima. Hasil ini mempunyai arti bahwa Kepuasan Kerja Berpengaruh Positif Terhadap kinerja. Artinya semakin puas karyawan terhadap pekerjaan yang mereka lakukan di PT. Nadia Kencana maka semakin tinggi pula tingkat kinerja karyawannya. Hasil penelitian ini sesuai dengan hipotesis yang diajukan dan juga sesuai dengan hasil penelitian yang dilakukan oleh Mathis \& Jackson (2004), Putrana (2016), Hasibun (2012), Devi (2009), Robbins (2006), yang menyatakan bahwa kepuasan 
kerja berpengaruh positif dan signifikan terhadap kinerja. Artinya semakin puas karyawan terhadap pekerjaan yang mereka lakukan makan semakin tinggi pula tingkat kinerja karyawan tersebut.

Peran kepuasan kerja memediasi komunikasi terhadap kinerja karyawan menunjukkan bahwa pengaruh langsung Komunikasi terhadap Kepuasan Kerja adalah sebesar 0,669. Pengaruh langsung variabel Komunikasi terhadap kinerja karyawan sebesar 0,388. Pengaruh langsung variabel Kepuasan Kerja terhadap kinerja karyawan sebesar 0,512 . Hal ini berarti bahwa variabel kinerja karyawan lebih besar dipengaruhi oleh Kepuasan Kerja dari Komunikasi. Sedangkan pengaruh tidak langsung variabel Komunikasi terhadap kinerja karyawan melalui Kepuasan Kerja sebesar 0,343. Jadi pengaruh total variabel Komunikasi terhadap kinerja karyawan melalui Kepuasan Kerja adalah sebesar 0,730 Jadi dapat disimpulkan bahwa lebih besar total pengaruh Komunikasi terhadap kinerja karyawan yang melalui Kepuasan Kerja, daripada pengaruh langsung Komunikasi terhadap kinerja karyawan tanpa melalui variable Kepuasan Kerja. Hasil penelitian ini sesuai dengan hipotesis yang diajukan dan juga sesuai dengan Carriere dan Bourque (2009), menyatakan bahwa komunikasi dan kepuasan kerja positif dan signifikan terhadap kinerja karyawan. Gray dan Laidlaw (2002), mengemukakan bahwa kepuasan kerja memediasi pengaruh komunikasi terhadap kinerja karyawan.

Hasil penelitian ini memiliki implikasi teoritis dan praktis. Secara teoritis, hasil penelitian ini menunjukkan bahwa komunikasi dan kepuasan kerja berpengaruh positif dan signifikan terhadap kinerja karyawan. Dengan demikian, 
hasil penelitian ini memberi dukungan empiris dan dapat dinyatakan memperkuat hasil-hasil studi terdahulu. Secara praktis, penelitian ini diharapkan dapat memberikan manfaat bagi pemimpin dan karyawan di PT. Nadia Kencana. Pihak manajemen dan karyawan diharapkan dapat meningkatkan kinerja karyawan dalam perusahaan guna dapat menciptakan hasil kerja yang lebih efektif dan efisien. Selain itu penilitian ini juga diharapkan dapat menjadi ukuran dari kinerja karyawan di PT. Nadia Kencana. Berikut merupakan implikasi dari hasil PT Sejahtera Indobali Trada Cabang Tabanan yaitu :

Komunikasi adalah proses penyampaian pesan atau maksud yang dilakukan melalui satu pihak atau seseorang kepada pihak atau orang lain baik dilakukan secara langsung atau melalui media. Dalam perusahaan, komunikasi akan mempengaruhi kepuasan kerja karyawan, karena jika terjalin komunikasi yang baik antara karyawan dan atasan maka karyawan akan menjadi lebih puas. Hasil penelitian ini menunjukan bahwa komunikasi berpengaruh terhadap kepuasan kerja karyawan. Hal ini mengandung implikasi agar kedepannya pimpinan mampu menjalin komunikasi yang baik guna memberikan kepuasan kerja pada karyawan.

Komunikasi adalah sistem aliran yang menghubungkan dan kinerja antar bagian dalam organisasi sehingga menghasilkan suatu sinergi. Semakin tinggi atau baik komunikasi yang ada di perusahaan, maka akan semakin tinggi pula kinerja karyawan yang akan dihasilkan sehingga tujuan perusahaan akan tercapai. Hasil penelitian ini menunjukan bahwa komunikasi berpengaruh terhadap kinerja karyawan. Hal ini mengandung implikasi agar kedepannya pimpinan mampu 
membuat karyawan untuk meningkatkan kinerja karyawan sehingga tujuan dari perusahaan dapat tercapai.

Kepuasan kerja adalah seperangkat perasaan pegawai atau karyawan tentang menyenangkan atau tidaknya pekerjaan mereka. Semakin terpuaskan karyawan, maka karyawan akan semakin menunjukkan kinerja terbaiknya. Sebaliknya, jika karyawan tidak merasa puas dalam bekerja, maka dalam dirinya akan timbul rasa malas, sehingga akan berdampak pada menurunnya kinerja. Hasil penelitian ini menunjukan bahwa kepuasan kerja berpengaruh terhasap kinerja pegawai. Hal ini mengandung implikasi agar kedepannya pimpinan dapat merangsang karyawan untuk meningkatkan kinerja dari karyawan sehingga tujuan dari perusahaan dapat tercapai.

Kinerja karyawan merupakan hasil kerja yang dihasilkan seorang individu baik dari segi kualitas maupun kuantitas pekerjaannya dan dapat dipertanggung jawabkan dengan hasil kerja yang dihasilkan oleh karyawan sesuai jabatan ditempati di perusahaan. Hal ini mengandung implikasi agar kedepannya pemimpin dapat merangsang karyawan untuk meningkatkan kinerja dari karyawan guna dapat menciptakan hasil kerja yang lebih efektif dan efisien.

\section{SIMPULAN DAN SARAN}

Berdasarkan hasil analisis penelitian dan hasil pembahasan pada bab sebelumnya maka simpulan dari penelitian ini adalah komunikasi berpengaruh positif dan signfikan terhadap Kepuasan Kerja kerja karyawan. Hal ini 
menunjukan bahwa jika Komunikasi semakin meningkat maka akan dapat meningkatkan pula Kepuasan Kerja kerja karyawan.

Komunikasi berpengaruh positif dan signfikan terhadap kinerja karyawan. Hal ini menunjukan bahwa jika Komunikasi semakin meningkat maka dapat meningkatkan kinerja karyawan. Kepuasan Kerja berpengaruh positif dan signifikan terhadap kinerja karyawan. Hal ini menunjukkan bahwa semakin tinggi Kepuasan Kerja kerja karyawan maka dapat meningkatkan kinerja karyawan. Kepuasan Kerja secara positif dan signifikan memediasi pengaruh Komunikasi terhadap kinerja karyawan. Hal ini menunjukan bahwa Komunikasi memberikan dampak yang signifikan terhadap kinerja karyawan jika di mediasi oleh Kepuasan Kerja, yang berarti bahwa kinerja karyawan sangat tergantung pada tingkat Kepuasan Kerja dari karyawan tersebut dan juga tingkat Komunikasi karyawan.

Saran yang dapat diberikan berdasarkan hasil analisis dan pembahasan adalah PT. Nadia Kencana sebaiknya dapat lebih menjelaskan mengenai tugastugas yang diberikan kepada karyawan, karena ketika karyawan kurang memahami tugas-tugas apa saja yang harus diselesaikan di dalam perusahaan, maka akan membuat pemimpin dari perusahaan tersebut memberikan informasi yang berulang-ulang mengenai tugas-tugas yang harus diselesaikan oleh karyawan di PT. Nadia Kencana. Contoh : Menyampaikan tugas secara langsung kepihak yang bersangkutan.

PT. Nadia Kencana sebaiknya dapat lebih memperhatikan mengenai jaminan kesehatan yang diberikan kepada karyawan, karena ketika karyawan merasa mendapatkan tunjangan sesuai atas kinerja yang dilakukannya, dengan 
begitu karyawan akan tetap tinggal di dalam perusahaan. Contoh : Memberikan asuransi kepada karyawan. PT. Nadia Kencana sebaiknya dapat lebih memperhatikan kerja sama team antara atasan dan bawahan, sehingga tercapai tujuan perusahaan untuk memperoleh keuntungan, sehingga kesejahtraan karyawan menjadi lebih baik. Contoh : Pemimpi memberikan solusi untuk menyelesaikan masalah yang tidak dapat dipecahkan oleh karyawan. PT. Nadia Kencana sebaiknya sering melakukan kontrol kepada karyawan untuk mengetahui baik buruknya kinerja karyawan, sehingga bisa memperbaiki kesalahan yang bisa menimbulkan kerugian perusahaan. Contoh : Pemimpin terjun langsung untuk mengontrol dan mengawasi kegiatan perusahaan.

\section{REFERENSI}

Ali, Akbar and Haider, Jahanzaid. (2012). Impact of internal organizational communication on employee job satisfaction - Case of some Pakistani Bank, Global Advanced Research journal of management and Business Studies.Vol 1(x), pp 038-044

Ardana, Komang., Mujiati, Ni Wayan dan A.A Ayu Sriathi. (2012). Buku Ajar Perilaku Keorganisasian. Denpasar: Fakultas Ekonomi Universitas Udayana.

Ardiansyah, Dimas Okta. (2016). Pengaruh Komunikasi Terhadap Kinerja Karyawan Dengan DimediasiI Oleh Kepuasan Kerja. Fakultas Ekonomi dan Bisnis, Universitas Brawijaya

Awang, Zainudin, Junaidah Hanim Ahmad, and Nazmi Mohamed Zin. (2010). Modelling Job Satisfaction And Work Commitment Among Lecturers: A Case Of UiTM Kelantan. Journal of Statistical Modelling and Analytics, $1(2): 45-59$.

Carriere, Jules and Bourque, Christoper. (2009). The effects of organizational communication on job satisfaction and organizational commitment in a land ambulance service and the mediating role of communication satisfaction, Journal of career Development International. Vol 14, No 1, pp $29-49$. 
Davis Keith dan Newstrom W. John. (2007). Perilaku Dalam Organisasi, Edisi 7.Erlangga.

Devi, Eva Kris Diana. (2009). Analisis Pengaruh Kepuasan Kerja dan Motivasi terhadap Kinerja Karyawan dengan Komitmen Organisasional Sebagai Variabel Intervening (Studi pada Karyawan Outsourcing PT Semeru Karya Buana Semarang). Tesis. (diakses 7 Februari (2012)

Fahmi, Irham. (2016). Perilaku Organisasi. Alfabeta, Bandung.

Femi, Asamu Festus. (2014). The Impact of Communication on Workers' Performance in Selected Organisations in Lagos State Nigeria. IOSR Journal Of Humanities And Social Science, 19(8): 75-82.

Gray, Judy and Laidlaw, Heather. (2002). PartTime Employment And Communication Satisfaction In An Australia Retail Organization. Journal Of Employee Relations, (online). Vol. 24 no 2. Diakses (2015)

Handoko T. Hani. (2003). Manajemen. Yogyakarta: BPFE-Yogyakarta

Hariandja, Marihot Tua Efendi. (2002). Manajemen Sumberdaya Manusia Pengadaan, Pengembangan, Pengkompensasian, dan Peningkatan Produktivitas Pegawai.Jakarta: PT Gramedia

Hasan, Salwa Hayati., Aziz, Nasir., Adam, Muhammad. (2012). Pengaruh Lingkungan Kerja Terhadap Kinerja Aktivis pada Lembaga Swadaya Masyarakat Di Kota Banda Aceh. Jurnal Manajemen Pascasarjana Universitas Syiah Kuala, 1(1), h:1-22.

Hasibuan SP. Malayu. (2009). Manajemen Sumber Daya Manusia. Edisi Revisi. Jakarta: Bumi Aksara.

Hasibuan, Malayu, (2012), Manajemen Sumber Daya Manusia, Bumi Aksara, Jakarta

Javad, Eslami and Davood Gharakhani. (2012). Organizational Commitment and Job Satisfaction. ARPN Journal of Science and Technology, 2(2):85-91.

Kiswanto, M. (2010). Pengaruh Kepemimpinan dan Komunikasi Terhadap Kinerja Karyawan Kaltim Pos Samarinda. Jurnal Eksis, 6(1): 1267-1439.

Luthans, Fred, (1998). Organizational Behavior Elevent edition, Mc Growth-Hill Book co, Singapore.

Luthans, Fred. (2006). Perilaku Organisasi. Edisi ke-10. Yogyakarta: ANDI.

Manullang, Marihot. (2004). Manajemen Personalia. Yogyakarta : Gajah Mada University Press.

Masmuh, A, (2010). Komunikasi organisasi dalam perspektif teori dan praktek. Cetakan 2, Universitas Muhammadiyah Malang, Malang. 
Mathis, Robert L. dan Jackson, John H.. (2004). Human Resource management. 10th Edition. Natorp Boulevard: South Western. Diterjemahkan oleh Angelica Diana. 2006. Manajemen Sumberdaya Manusia. Edisi 10. Jakarta: Salemba Empat.

Novita, Nita., Salim, Ubud., dan Troena, Eka Afnan. (2002). Pengaruh Karakteristik Indi-vidu, Komunikasi Efektif dan Kepuasan Kerja terhadap Kinerja Karyawan (Studi pada karyawan Tetap PT. Tambang Batubara Bukit Asam). Malang: Universitas Brawijaya.

Panuju, Redi. (2001). Sistem Komunikasi Indonesia. Penerbit Pustaka Pelajar.

Purwanto Sony Bagus. (2013). Pengaruh Komunikasi,Motivasi dan Kepuasan Kerja Terhadap Kinerja Karyawan ( Studi Pada Proyek Pondasi Tower Di Timor Leste PT. Cahaya Inspirasi Indonesia).

Putrana, Yoga, (2016), Pengaruh Kepuasan Kerja Dan Komitmen Organisasi Terhadap Organizational Citizenship Behavior (OCB) Dalam Meningkatkan Kinerja Karyawan Pada PT. Gelora Persada Mediatama Semarang, Journal Of Management, Volume 2 No.2 Maret (2016)

Razi, Nazila and Elizabeth More. (2010). The role of communicationin the acquisition of high performance work system organisations. Australian Journal of Communication, Vol. 37, Edisi 1,page 55-74.

Rivai, Veithzal, (2004). Kepemimpinan dan Perilaku Organisasi, Edisi Kedua,Raja Grafindo Persada, Jakarta.

Robbins, Stephen P. (2001). Perilaku Organisasi. Edisi Ke Delapan, Jilid 1 \& 2. Jakarta: PT. Prihalindo.

Robbins, S. P. (2003). Perilaku Organisasi, Jilid 2. Jakarta: PT. Indeks Kelompok Gramedia.

Robbins, Stephen P. (2006). Perilaku Organisasi. Edisi Kesepuluh, Edisi Lengkap. Jakarta : PT Indeks

Robbins, Stephen P., dan Judge, Timoty A. (2008). Perilaku Organisasi (Organizational Behavior), Terjemahan: Diana Angelica, Ria Cahyani dan Abdul Rosyid, Buku 2, Edisi 12. Jakarta: Salemba Empat.

Robbins, Stephen P. (2009). Perilaku Organisasi, Buku 1. Jakarta: Penerbit Salemba Empat

Sobel, M. E. (1982). Asymptotic confidence intervals for indirect effects in structural equation models. Sociological methodology, 13(1982), 290312 .

Sudarmanto.2009. Kinerja dan Pengembangan Kompetensi SDM. Yogyakarta: Pustaka Pelajar 
Sudiro, Achmad dan Sumanang, Nona F. A.(2005). Pengaruh Komunikasi yang Efektif dalam Organisasi terhadap Kepuasan Kerja Karyawan pada Bagian Produksi (Studi Pada PT Tirta Investama Pandaan). Tesis. Malang: Universitas Brawijaya.

Sumarsan, Thomas, (2013). Sistem Pengendalian Manajemen. Indeks, Jakarta.

Trijaya. (2012). Pengaruh Kompensasi, Pendidikan dan Pelatihan, Komunikasi dan Motivasi terhadap Kinerja Karyawan. Tesis. Fakultas Ekonomi Universitas Indonesia.

Utamajaya, I., \& A. Sriathi. (2015). Pengaruh Motivasi, Komunikasi, Serta Lingkungan Kerja Fisik Terhadap Semangat Kerja Karyawan Pada Fuji Jaya Motor Gianyar. E-Jurnal Manajemen Universitas Udayana, 4(6).

Vidianingtyas,Renggani nur'aini dan Wika Harisa Putri.(2014). Pengaruh Kompensasi, Kepusan Kerja, Motivasi Kerja Dan Gaya Kepemimpinan terhadap Kinerja Karyawan Pada Perusahaan Jasa Ketering di Daerah Istimewa Yogyakarta. Jurnal Bisnis dan Ekonomi,5(1),pp:99-110. 